\title{
Tingkat Pengetahuan dan Pemahaman Masyarakat terhadap Konsep Perumahan Berbasis Syariah di Provinsi Jambi
}

\author{
Supeno $^{1 *}$, Mhd. Ansori ${ }^{2}$, Melly Susiandari ${ }^{3}$, Putri Anelia Anmas ${ }^{4}$, Indah Sundari ${ }^{5}$ Afihilia Rizky Saffanah ${ }^{6}$, \\ Puti Indah Rahmaya ${ }^{7}$ \\ 1,2,3,4,5,6,7 Fakultas Hukum Universitas Batanghari Jambi \\ *Correspondence email: msasyabani@gmail.com
}

\begin{abstract}
Abstrak. Penelitian ini bertujuan untuk mengetahui bagaimana tingkat pengetahuan dan pemahaman masyarakat terhadap konsep perumahan berbasis syariah, di Propinsi Jambi. Penelitian ini menggunakan metode penelitian empiris dengan menggunakan metode penyebaran angkat berupa daftar pertanyaan (quisioner0 langsung terhadap masyarakat yang berada di Propinsi Jambi, dengan mengambil sampel sebanyak 4 (emapt) kota/kabupaten yaitu Kota Jambi, Kabupaten Muaro Jambi, Kabupaten Merangin, Kabupaten Muara Bungo dan Kabupaten Kerinci. Dengan dilakukannya penelitian ini akan diperoleh informasi tingkat pemahaman masyarakat dan tingkat peahaman masyarakat tentang konsep perumahan berbasisi syariah. Dari hasil penelitian dapat disimpulkan bahwa mayoritas masyarakat yang ada dalam Propinsi Jambi telah mengetahui adanya program kepemilikan rumah dengan system Syariah, sedangkan mayoritas masyarakat yang ada dalam Propinsi Jambi belum mengetahui prosedur kepemilikan rumah dengan menggunakan system Syariah; dan mayoritas masyarakat telah memahami bahwa pembelian perumahan dengan menggunakan system Syariah lebih menguntungkan ekonomi masyarakat, berkontribusi dalam pengembangan ekonomi umat, memahami bahwa pembelian perumahan dengan system Syariah bebas dari riba, sita dan denda serta memahami kerugian yang dialami jika bertransaksi dengan riba.
\end{abstract}

Kata kunci: pengetahuan; pemahaman; perumahan; syariah

Abstract. This research aims to find out how the level of knowledge and understanding of the community towards the concept of sharia-based housing, in Jambi Province. This research uses empirical research method using the method of disseminating lift in the form of a list of questions (quisioner0 directly to the people located in Jambi Province, by sampling as many as 4 (emapt) cities / districts namely Jambi City, Muaro Jambi Regency, Merangin Regency, Muara Bungo Regency and Kerinci Regency. With the conduct of this research will be obtained information on the level of understanding of the community and the level of community understanding about the concept of sharia-based housing. From the results of the study can be concluded that the majority of people in Jambi Province have been aware of the home ownership program with sharia system, while the majority of people in Jambi Province do not know the procedure of home ownership using sharia system; and the majority of the public has understood that the purchase of housing using the Sharia system is more beneficial to the community economy, contributes to the economic development of the people, understands that the purchase of housing with sharia system is free from usury, confiscation and fines and understands the losses experienced if transacting with usury.

Keywords: knowledge; understanding; housing; syariah

\section{PENDAHULUAN}

Penelitian ini merupakan penelitian lanjutan dari penelitian Tahun 2019 Tentang Pengembangan Perumahan Berbasis Syariah dan Permasalahannya di Propinsi Jambi. Dalam penelitian yang dilakukan pada tahun 2019 tersebut dapat diperoleh beberapa informasi penting yang dituangkan dalam hasil penelitian yaitu:

Pakar Ekonomi Syariah Indonesia Muhammad Arifin Badri telah menulis dalam bukunya yang berjudul Panduan Praktis Fikih Perniagaan Islam berpendapat "syariat Islam konsisten mengajar kemuliaan, bukan hanya mengajarkan kemuliaan, Islam secara tegas telah melarang umatnya dari segala bentuk kehinaan (Arifin Badri, 2015), satu bentuk kehinaan adalah praktik riba yang dipraktikkan oleh bank konvensional, masalah riba secara jelas dilarang baik yang tertuang di dalam AlQur'an maupun Al-Hadist." Riba adalah salah satu hal yang diharamkam dalam Agama Islam. Banyak sekali dalil yang menegaskan tentang keharaman riba dan berbagai sarana terjadinya riba." (Arifin Badri, 2015). Menurut Pakar Muammalah Kontemporer Erwandi Tarmizi (2016) mengatakan bahwa "tidak ada seorang muslimpun yang menyangkal haramnya riba. Alqur'an begitu jelas menyatakan bahwa Allah mengharamkan riba (Erwandi, 2016). Secara tegas diatur dalam Surah Al-Baqarah: 278, Surah Al-Baqarah: 279.

Pendidikan terhadap masyarakat tentang perjanjian syariah di Indonesia saat ini menunjukan trend yang cenderung semakin meningkat, tingkat pengetahuan dan kesadaran masyarakat Indonesia terhadap transaksi yang dibolehkan dan dilarang semakin tinggi, secara periodik dan bertahap masyarakat mulai meninggalkan transaksi riba. Hasil positifnya adalah semakin banyak masyarakat yang beralih dari bank konvensional ke bank syariah, hal ini merupakan kondisi yang patut disyukuri dan menjadi. Tugas 
pemerintah adalah membuka akses yang seluas-luasnya pelayanan bank syariah agar dapat dijangkau oleh seluruh lapisan masyarakat.

Bank Islam adalah "bank yang beroperasi tanpa mengandalkan kepada bunga, bank Islam disebut pula dengan bank tanpa bunga (riba) adalah lembaga keuangan/perbankan yang dilaksanakan dan kembangkan berdasarkan pada Al-Qur'an dan Hadist. (Viethal Rivai, 2013), Ciri utama dari bank syariah adalah bebas dari segala macam bentuk praktik riba. Secara yuridis bank Syariah didirikan berdasarkan Undang-Undang Nomor 21 Tahun 2008 Tentang Perbankan Syariah, pendirian perbankan syariah bertujuan untuk menunjang pelaksanaan pembangunan nasional dalam rangka meningkatkan keadilan, kebersamaan, dan pemerataan kesejahteraan rakyat. Bank Syariah mengemban tugas yang mulia yaitu untuk mencapai kesejahteraan rakyat, masyarakat berharap agar bank syariah dapat mengemban tugas tersebut dengan baik dan benar-benar dapat meningkatkan kesejahteraan rakyat.

Kredit Pemilikan Rumah (KPR) pada perbankan syariah berbeda dengan Konsep Kredit Pemilikan Rumah (KPR) yang ada di perbankan konvensional. Perbedaan ini terlihat pada perbedaan prinsip antara perbankan syariah dengan perbankan konvensional. Dalam perbankan syariah dikenal konsep berbasis bagi hasil, dalam perbankan konvensional menerapkan sistem yang berbasis riba. Produk yang dikenal dengan nama Kredit Pemilikan Rumah (KPR) syariah ini terdapat beberapa karakteristik di antaranya tidak adanya pemberlakuan sistem kredit yang ada pada perbankan konvensional. Sementara pada perbankan syariah dikenal sistem murabahah yang berbasis margin, musyarakah mutanaqisah yang memiliki ciri khas partisipasi kepemilikan.

Kredit Pemilikan Rumah (KPR) syariah dapat menggunakan akad murabahah yang berbasis jual beli. Pada perbankan syariah konsep murabahah merupakan konsep perdagangan berbasis jual beli yang pembayarannnya dilakukan secara tangguh atau kredit. Dalam akad ini pihak bank syariah bertindak sebagai penjual yang akan melakukan penjualan aset kepada nasabahnya secara tangguh atau dengan cicilan/kredit. Dalam akad murabahah pihak bank syariah akan melakukan penjualan barang dagangan kepada para nasabahnya dengan keuntungan yang telah disepakati oleh kedua belah pihak. Akad KPR syariah yang menggunakan sistem murabahah membuat pihak bank syariah harus memberitahukan kepada nasabahnya berkaitan dengan harga perolehan rumah yang diperoleh bank syariah dari pihak pengebang. Bank syariah dengan harga tersebut kemudian menetapkan keuntungan yang akan diperolehnya di mana keuntungan tersebut disepakati oleh kedua belah pihak.
PT. Mitra Inspira Madani (MMI) merupakan perusahaan pengembang perumahan yang ada di Propinsi Jambi, perusahaan dipimpin oleh Muchdian, ST ini telah membangun perumahan di Jalan Bluru Desar Mekar Jaya Kabupaten Muaro Jambi dan di beberapa tempat di wilayah Kota Jambi dengan konsep syariah, ke depannya akan membangun perumahan di Desa Sungai Duren, PT. Mitra Inspira Madanai (MMI) telah membangun dan memasarkan sebanyak 67 unit rumah. Konsep syariah yang dikembangkan oleh PT. Mitra Inspira Madani adalah merujuk kepada konsep transaksi syariah yaitu transaksi jual beli yang tidak mengandung unsur riba, rumah sudah dibangun perusahaan terlebih dahulu kemudian baru dipasarkan kepada masyarakat, bukan dibangun setelah akad perjanjian ditandatangani, tidak ada penerapan denda keterlambatan, jika pun konsumen tidak sanggup lagi untuk melanjutkan kreditnya maka perusahaan akan memfasilitasi konsumen untuk menjual rumahnya kepada pihak lain, dari hasil penjualan akan ditetapkan uang pelunasan sisa kredit dan sisa hasil penjualan akan menjadi milik konsumen.

Konsep pengembangan perumahan berbasis syariah oleh PT. Mitra Inspira Madanai (MMI) sangat membantu masyarakat yang belum memiliki rumah terutama bagi masyarakat yang tidak mampu, betapa tidak praktik ini akan menghindari kedua belah pihak pihak terlibat dalam parktik riba sehingga terhindar dari perbuatan dosa, akibat dari transaksi riba yang dikembangkan oleh transaksi ribawi dengan adanya pertambahan dan denda keterlembatan dimana konsumen tidak mampu lagi untuk membayar tidak sedikit dari masyarakat yang harus kehilangan uang yang sudah disetor dan kehilangan rumah yang sudah dibeli, karena itu sudah menjadi pemandangan yang biasa hampir di setiap perumahan yang menggunakan konsep ribawi ada saja rumah yang disita oleh bank, dilelang oleh bank dan konsumen kehilangan haknya atas tanah dan rumah tersebut.

Dalam konsep syariah jika terjadi sengketa maka akan diupayakan dulu melalui jalur musyawarah, jika tidak dapat diselesaikan secara musyawarah maka dapat diselesaikan melalui jalur hukum sebagaimana yang tertuang di dalam surat perjanjian yang ditandatangani oleh kedua belah pihak, Hasil Wawancara dengan Muchdian, ST pada tanggal 14 Agustus 2019, sampai saat ini tidak ada sengketa yang terjadi antara kedua belah pihak. Diakuinya bahwa konsep perumahan berbasis syariah merupakan model transaksi yang jauh dari timbulnya perselisihan dengan syarat kedua belah pihak memiliki itikad baik dalam menjalankan perjanjian yang sudah disepakati oleh kedua belah pihak.

Dalam transaksi perumahan berbasis syariah, ada beberapa pola yang dikembangkan oleh PT. Mitra Inspira Madanai (MMI) yaitu: 
a. Pembelian secara langsung antara pengembang dengan konsumen yang dapat dilakukan secara kontan maupun secara kredit;

b. Pembelian melalui bank syariah, di mana pengembang menjual perumahan kepada bank syariah selanjutnya bank syariah menjual kepada konsumen yang dapat dilakukan secara kontan maupun secara kredit

Hasil wawancara dengan Ahmad Rupandi selaku bagian pemasaran PT. Amanah Umat Sukses (AUS) pada tanggal 14 Agustus 2019; Perumahan berbasis syariah yang dibangun oleh PT. Amanah Umat Sukses (AUS) Kredit Syariah juga mengemban misi untuk memperkenalkan konsep perumahan syariah yaitu untuk menghilangkan praktik riba, kedzaliman berupa denda keterlambatan dan sita. PT. Amanah Umat Sukses (AUS) ingin memberikan solusi bagi masyarakat yang ingin memiliki rumah tanpa riba, pada saat ini PT. Amanah Umat Sukses (AUS) sudah menyediakan 24 (dua puluh empat) kavling tanah perumahan siap bangun di Desa Mendalo Darat Kabupaten Muaro Jambi dan beberapa kavling tanah untuk rumah.

Wawancara by phone dengan Hasbi Munawar, S.T selaku Direktur PT. Amanah Umat Sukses (AUS) Kredit Syar'i; Konsep pengembangan yang dilakukan oleh PT. Amanah Umat Sukses (AUS) Kredit Syar'i yaitu konsumen membeli secara langsung kepada pengembang dengan 2 (dua) macam pola yang dapat dipilih oleh konsumen yaitu kontan dan kredit, ada dua bentuk transaksi yaitu pertama dapat membeli tanah kavlingnya saja atau sekalian dibangunkan rumah oleh pengembang, untuk bentuk yang pertama jika akan membangun rumah sendiri konsep bagian depan rumah harus seragam dengan konsep rumah yang dibangun oleh pengembang.

Pada dasarnya konsep pengembangan perumahan berbasis syariah ini adalah pertama untuk menghidupkan konsep transaksi yang dihalalkan oleh Allah yaitu bebas dari transaksi riba, bebas dari praktik kedzaliman yaitu bebas dari praktik denda dan bebas dari sita oleh bank, kedua memberikan solusi utama kepada masyarakat yang ingin memiliki rumah secara dengan harga terjangkau tanpa melalui bank konvensional, selama ini yang terjadi dalam masyarakat telah banyak yang menjadi korban pada saat mereka tidak mampu lagi untuk menyicil rumah mereka sehingga banyak diantara rumah mereka disita oleh bank. Dalam hal ini bank akan tetapi menjadi pihak yang untung sedangkan konsumen menjadi pihak yang dirugikan.

Secara umum di Jambi dibandingkan antara masyarakat yang menyadari tentang larangan bertransaksi riba dengan masyarakat yang sudah memahaminya masih sangat timpang jumlahnya, yaitu mayoritas lebih dominan yang belum memahami bahaya riba, oleh karena itu jika perumahan yang ditawarkan kepada masyarakat umum mereka lebih percaya dengan rumah subsidi yang disediakan oleh pemerintah. (Hasil Wawancara dengan Muchdian, ST pada tanggal 14 Agustus 2019).

Oleh karena itu konsumen yang membeli perumahan yang dibangun Mitra Inspirasi Madani adalah mereka yang sudah mengenal dan memahami konsep syariah. Permasalahan lain yang dihadapi oleh PT. Mitra Inspira Madani dalam mengembangkan perumahan berbasis syariah adalah pada saat mengurus berbagai macam perizinan, yaitu masih ada praktik menghambat perizinan yang dilakukan oleh oknumoknum tertentu yang tidak bertanggung jawab, akan tetapi PT. Mitra Inspira Madani tetapi melaksanakan prosedur yang ditetapkan dan tidak melayani berbagai macam upaya untuk melakukan rasuah walaupun konsekuensinya terbitnya surat izin relatif lebih lama.

Menurut Ahmad Rupandi, Staf Pemasaran PT.Amanah Umat Sukses (AUS) Kredit Syar'i, pada tanggal 14 Agustus 2019Sejauh ini secara umum permasalahan yang dihadapi PT. Amanah Umat Sukses (AUS) Kredit Syar'i adalah masyarakat masih cenderung memilih perumahan dengan konsep konvensional, belum begitu memahami konsep perumahan syariah, oleh karena itu mayoritas konsumen yang membeli tanah kavling dan perumahan PT. Amanah Umat Sukses (AUS) Kredit Syar'i adalah masyarakat dalam komunitas terbatas yang telah memahami konsep perumahan syariah. Dalam masalah pengurusan perizinan PT. Amanah Umat Sukses (AUS) Kredit Syar'i tidak menemukan hambatan dan permasalahan yang berarti karena pada saat ini baru hanya terbatas pada pembelian objek perumahan dan belum pada tahap pembangunan perumahan.

Dengan demikian secara umum kendala yang dihadapi oleh para pengembang dalam mengembangkan perumahan berbasis syariah ini tingkat pengetahuan dan kesadaran masyarakat terhadap konsep syariah masih rendah hal ini bisa dilihat masih minimnya minat masyarakat umum yang membeli perumahan berbasis syariah, dan pada umumnya yang membeli rumah adalah mereka yang telah memiliki ilmu syar'i sehingga hanya dalam komunitas yang terbatas. Sedangkan permasalahan yang dihadapi adalah masih adanya upaya yang dilakukan oleh oknum oknum tertentu yang menghambat dalam proses perizinan dengan berbagai macam trik sehingga menghambat terbitnya berbagai macam perizinan yang harus dimiliki pengembang.

Dari hasil penelitian kompetitif yang telah dilakukan tersebut, menunjukkan bahwa di Propinsi Jambi sudah berdiri dan berkembang pengembang perumahan yang membangun perumahan dengan menggunakan prinsip Syariah, hal ini tentu suatu hal yang sangat menggembirakan, akan tetapi jika ditilik dari dari jumlah pengembang yang ada di propinsi Jambi prosentasenya masih sangat rendah dibandingkan dengan perusahaan yang menggunakan jasa bank 
konvensional, beberapa penyebab adalah tingkat pengetahuan dan kesadaran para pengembang dan masyarakat yang masih dipertanyakan karena keberhasilan suatu program sudah barang tentu harus diukur seberapa besar tingkat pengetahuan dan kesadarannya.

Berdasarkan praaduga tersebut maka perlu dilakukan penelitian lebih lanjut untuk mengukur tingkat pengetahuan dan kesadaran masyarakat dalam memanfaatkan perumahan yang berbasis Syariah. Berdasarkan data dan fakta yang telah diungkapkan di atas, maka dapat disusun rumusan masalah yaitu bagaimana tingkat pengetahuan masyarakat tentang konsep perumahan berbasis syariah di Propinsi Jambi dan bagaimana tingkat pemahaman masyarakat untuk memiliki rumah berbasis Syariah di Propinsi Jambi.

\section{METODE}

\section{Tipe Penelitian}

Sebagai konsekuensi pemilihan topik yang akan dikaji dalam penelitian yang objeknya adalah permasalahan tentang tingkat pemahaman dan kesadaran masyarakat tentang konsep perumahan berbasis syariah di Propinsi Jambi, maka tipe penelitian yang digunakan adalah penelitian empiris, yakni penelitian yang difokuskan untuk mengkaji secara langsung kepada objek penelitian yaitu masyarakat umum yang belum memiliki rumah.

\section{Sumber data}

Dalam melakukan penelitian ini sumber data yang dipergunakan adalah terdiri atas 2 (dua) sumber data yaitu:

a. penelitian lapangan (field research)

Yaitu dengan cara melakukan penelitian langsung ke masyarakat, dengan demikian akan diperoleh informasi yang akurat dan objektif tentang tingkat pengetahuan dan kesadaran masyarakat tentang konsep perumahan berbasis Syariah.

b. Penelitian kepustakaan (library research)

Penelitian kepustkaan dimaksudkan agar penelitian lapangan yang telah dilakukan dapat diperkuat oleh arguen-argumen hukum dan teori oleh para ahli yaitu dengan cara menelaah peraturan perundang-undangan maupun berbagai macam sumber buku yang memiliki keterkaitan dengan penelitian yang dilakukan.

\section{Teknik penarikan sampel}

Dalam penelitian ini teknik pengumpulan data yang dilakukan adalah secara random sampling yaitu dengan mengacak masyarakat yang memiliki potensi untuk memiliki rumah berusia antara 19 sampai 25 tahun di wilayah Kota Jambi, Kabupaten Muaro Jambi, Kabupaten Merangin dan Kabupaten Kerinci, masingmasing kabupaten diambil sekitar 10 sampai 20 sebagai saampel.

\section{Teknik pengumpulan data}

Teknik pengumpulan data yang dilakukan adalah dengan cara wawancara langsung dan mengisi angket yang telah disediakan yang dituangkan dalam berbagai macam pertanyaan yang disusun secara sistematis dan terukur untuk memperoleh jawaban- jawaban atas informasi yang ingin diperoleh yaitu tentang tingkat pengetahuan dan pemahaman masyarakat untuk memiliki perumahan berbasis syariah, data yang telah diperoleh akan diseleksi dan ada hubungan dengan permasalahan tersebut diklasifikasi sesuai dengan tingkat relevansinya.

\section{Analisis data}

Data yang diperoleh kemudian dianalisis dan dikaji dan menarik kesimpulan dari semua permasalahan yang dibahas secara induktif, kajian dilakukan sedemikian rupa sehingga menggambarkan permasalahan dan pemecahannya secara jelas dan komprehensif.

\section{HASIL DAN PEMBAHASAN}

Tingkat pengetahuan masyarakat tentang konsep perumahan berbasis syariah di Propinsi Jambi

Pengetahuan menurut Notoatmojo adalah hasil tahu dari manusia dan terjadi setelah orang melakukan penginderaan terhadap objek tertentu. Penginderaan terjadi melalui panca indra manusia yaitu penglihatan, pendengaran, penciuman, rasa dan raba.( Silabus.web.id), pengetahuan merupakan hasil proses dari penginderaan melalui panca indera terhadap objek tertentu, pada saat seseorang ingin mengetahui sesuatu maka akan mendekati objek tersebut kemudian melihat dengan seksama, atau mendengar dengan seksama sumber suara atau informasi atau melalui proses perbaan dan penciuman, pengetahuan dapat diperoleh baik melalui sekali proses maupun beberapa kali proses penginderaan tergantung rumit tidaknya objek yang ingin diketahui.

Dalam penelitian ini; yang pertama ingin diukur adalah tingkat pengetahuan masyarakat terhadap konsep perumahan berbasis syariah di Propinsi Jambi. Penelitian yang dilakukan antara bulan Maret 2020 sampai bulan Juli 2020 yang bertepatan dengan terjadinya pandemi Covid-19 di hampir seluruh negara di dunia, dalam penelitian ini dilakukan secara online Google form) yang disebar di 4 (empat) kota dan kabupaten yang ada di Propinsi Jambi dari 11 Kabupaten/Kota yang ada di propinsi Jambi yaitu Kota Jambi, Kabupaten Muaro Jambi, Kabupaten Merangin, Kabupaten Muara Bungo dan Kabupaten Kerinci. Dari 4 (empat) kabupaten/kota tersebut dapat dijaring responden dengan data sebagai berikut:

a. Jumlah responden : 628 responden

b. Rata-rata pekerjaan : Mahasiswa (45\%) 
: ASN $(25 \%)$

: Wiraswasta (15)

: Karyawan Swasta $(10 \%)$

: Lain-lain (5\%)

\section{c. Rentang usia : 14 sampai 58 tahun}

Dari data tersebut tergambar bahwa mayoritas responden sebesar $45 \%$ adalah mahasiswa yang merupakan responden yang kritis dan terpelajar, dan mahasiswa merupakan responden yang rata-rata belum memiliki rumah yang memiliki potensi untuk segera terjun ke dunia kerja dan memiliki keinginan untuk membina rumah tangga dan sejatinya harus memiliki rumah, urutan kedua adalah Aparatur Sipil Negara (ASN) sebesar $25 \%$, merupakan komponen yang ratarata sudah berkeluarga dan memiliki rumah terutama rumah di kawasan perumahan, ketiga adalah dari kalangan wiraswasta yang memiliki usaha mandiri sebesar $15 \%$ walaupun sebagian besar dari wirausahawan ini telah memiliki rumah sendiri baik di Kawasan perumahan maupun tidak, selebihnya adalah karyawan swasta sebesar $10 \%$ dan sisanya dari berbagai macam profesi sebesar $5 \%$. Sedangkan usia yang memberi respon dalam penelitian ini berusia antara 14 tahun sampai 58 tahun yang mayoritas merupakan usia produktif seorang manusia.

Jumlah responden yang berhasil dihubungi dan telah memberikan jawaban sebanyak 628 responden dari Kota Jambi, Kabupaten Muaro Jambi, Kabupaten Muaro Bungo, Kabupaten Merangin dan Kabupaten Kerinci diperoleh dengan menampilkan 10 pertanyaan dengan 3 (tiga) opsi jawaban, data yang diperoleh dari penelitian ini adalah sebagai berikut:

\begin{tabular}{|c|c|c|c|c|}
\hline No & Pertanyaan & Ya & Tidak & Ragu-Ragu \\
\hline 1 & Apa Saudara Memiliki Rumah? & $36.1 \%$ & $63.9 \%$ & - \\
\hline 2 & Apa Saudara Ingin Memiliki Rumah Di Kawasan Perumahan? & $49.5 \%$ & $26.3 \%$ & $24.2 \%$ \\
\hline 3 & $\begin{array}{l}\text { Apakah Saudara Mengetahui Sistem Pembelian Rumah Yang dijalankan } \\
\text { Bank Konveksional? }\end{array}$ & $42.4 \%$ & $57.6 \%$ & - \\
\hline 4 & $\begin{array}{l}\text { Apakah Saudara Mengetahui Bahwa Sekarang Sudah Ada Penjualan } \\
\text { Perumahan Dengan Sistem Syariah? }\end{array}$ & $61.8 \%$ & $38.2 \%$ & - \\
\hline 5 & Apakah Saudara Mengetahui Prosedur Memiliki Rumah Sistem Syariah? & $18.8 \%$ & $81.2 \%$ & - \\
\hline 6 & $\begin{array}{l}\text { Apakah Saudara Mengetahui Bahwa Prosedur Pembelian Rumah Sistem } \\
\text { Syariah Lebih Mudah Dan Cepat? }\end{array}$ & $31.2 \%$ & $68.8 \%$ & - \\
\hline 7 & $\begin{array}{l}\text { Apakah Saudara Memahami Bahwa Pembelian Rumah Dengan Sistem } \\
\text { Syariah Lebih Menguntungkan Ekonomi Saudara? }\end{array}$ & $55.1 \%$ & $44.9 \%$ & - \\
\hline 8 & $\begin{array}{l}\text { Apakah Saudara Memahami Bahwa Bertransaksi Dengan Sistem Syariah } \\
\text { Telah Berkonstribusi Dalam Pengembangan Ekonomi Umat? }\end{array}$ & $43.2 \%$ & $21 \%$ & $35.8 \%$ \\
\hline 9 & $\begin{array}{l}\text { Apakah Saudara Memahami Bahwa Pembelian Rumah Dengan Sistem } \\
\text { Syariah Bebas Dari Riba, Denda Dan Sita? }\end{array}$ & $54.5 \%$ & $45.5 \%$ & - \\
\hline 10 & $\begin{array}{l}\text { Apakah Saudara Memahami Kerugian Pembelian Rumah Yang Mengandung } \\
\text { Unsur Riba, Denda Dan Sita? }\end{array}$ & $58.3 \%$ & $41.7 \%$ & - \\
\hline
\end{tabular}

Dari hasil penelitian diperoleh data bahwa sebagaian besar responden belum memiliki rumah $(63,9)$ sedangkan yang sudah memiliki rumah sebesar $36,1 \%$, mayoritas responden berkeinginan memiliki rumah di Kawasan perumahan $(49,5)$, yang tidak berminat sebesar $(26,3 \%)$ sedangkan yang tidak mengambil sikap (raguragu) sebesar 24, $2 \%$. Data ini menggambar bahwa responden lebih cenderung ingin memiliki rumah di Kawasan perumahan, secara umum rata-rata yang menjadi dasar pertimbangannya adalah:

a. Pembelian rumah di Kawasan perumahan dapat dilakukan dengan cara kredit;

b. Tidak perlu mengurus surat-surat tanah, rata-rata tanah perumahan telah bersertifikat, sudah memiliki Izin Mendirikan Bangunan (IMB) dan sebagainya;

c. Menghindari terjadinya tumping tindih sertifikat dan sengketa tanah;

d. Perumahan telah tersedia parasarana jalan dan sarana air bersih, listrik dan sebagainya;

e. Perumahan ada yang menyediakan fasilitas umum seperti sekolah, musholla, tempat olahraga dan bermain.
Berkaitan dengan tingkat pengetahuan masyarakat terhadap konsep perumahan berbasis Syariah adalah sebagai berikut:

a. Berkaitan dengan pengetahuan masyarakat tentang Sistem Pembelian Rumah Yang dijalankan Bank Konveksional, yang sudah memahami adalah sebesar $42,4 \%$, sedangkan yang belum mengetahui tentang system pembelian rumah di kawasan perumahan yang dijalankan oleh bank konvensional yaitu sebesar 57,6 $\%$. Angka ketidaktahuan masyarakat mengakibatkan masyarakat terjebak dalam system ribawi yang dijalankan oleh bank konvensional seperti denda keterlambatan, sita dan sebagainya. KPR syariah tanpa bank pada dasarnya kredit dimana para pembeli rumah tidak menggunakan bank dalam praktinya sehingga pembeli rumah langsung membayar cicilan kepada developer. Proses KPR syariah tanpa bank berbeda dengan KPR biasa menggunakan bank. KPR syariah tanpa bank dipercayai dapat lebih memudahkan pelanggan karena pelanggan tidak diharuskan berurusan dengan hal administratif yang sering kali membebani. KPR syariah tanpa bank 
dianggap memiliki fleksibilitas tinggi karena memiliki berbagai fitur sebagai berikut; tidak ada BI checking, tidak memerlukan slip gaji atau SK sehingga cocok untuk para pengusaha non formal seperti para pedagang, tanpa sita, tanpa denda, dan tanpa riba (Ergi Arvian, 2017)

b. Berkaitan dengan tingkat pengetahuan masyarakat tentang adanya system pembelian rumah dengan menggunakan Sistem Syariah, sebanyak 61,8 \% responden telah mengetahui adanya sistem pemilikan rumah dengan system Syariah,

c. Berkaitan dengan tingkat pengetahuan masyarakat tentang prosedur memiliki rumah yang menggunakan system Syariah, 18,8 \% masyarakat sudaah mengetahui prosedur kepemilikan rumah dengan system Syariah sedangkan yang belum mengetahui prosedur kepemilikan rumah system Syariah $81.2 \%$, dengan demikian mayoritas responden belum mengetahui bagaimana prosedur memiliki rumah yang menggunakan sistem Syariah, hal ini terjadi karena sebagian besar responden belum mempelajari bagaimana system pembelian rumah secara kredit secara Syariah, begitu banyak literatur yang dapat dicari baik melalui media cetak berupa buku maupun media elektronik berupa internet yang dimuat di gogle, youtube, instragram, facebook dan sebagainya. Dengan informasi yang memadai masyarakat akan terhindar dari praktik yang salah yang dilakukan oleh developer yang mengatasnamakan Syariah, karena nama tidak menjamin bahwa system yang dilakukan sesuai dengan Syariah, karenanya yang harus dilihat adalah isi perjanjian dan skema yang dilakukan apakah sesuai dengan prinsip-prinsip Syariah atau tidak. Dalam menjalankan produk KPR,bank syariah melakukan penggalian danpemaduan terhadap skimskim transaksi,hal ini bertujuan untuk menciptakan suatubentuk transaksi pembiayaan pemilikanrumah yang sesuai dengan dengan prinsipsyariah. Adapun yang menjadi acuanadalah pelaksanaan KPR pada bankkonvensional, karena pada dasarnyakeberadaan bank syariah adalahperwujudan dari kekurangpuasan umat Islam terhadap bank konvensionalsehingga mengupayakan bentuk transaksiperbankan yang sesuai dengan prinsip Islam (Arief Hidayatullah, 2017).

d. Berkaitan tentang tingkat pengetahuan masyarakat tentang bahwa prosedur pembelian rumah sistem syariah lebih mudah dan cepat, sebanyak $31,2 \%$ masyarakat telah mengetahui bahwa prosedur pembelian perumahan system Syariah lebih mudah dan cepat, sedangkan $68,8 \%$ belum mengetahuinya, mengapa dikatakan lebih cepat dan mudah karena nasabah hanya berhubungan dengan pemilik perumahan baik developer atau bank Syariah yang sudah membeli rumah dari developer langsung sehingga tidak terjadi transaksi segi tiga yang selama ini dilakukan oleh developer dan bank konvensional.

\section{Tingkat pemahaman masyarakat terhadap konsep perumahan berbasis Syariah di Propinsi Jambi}

Dari data hasil penelitian di atas dapat disimpulkan bahwa mayoritas masyarakat Propinsi Jambi sudah mengetahui dan memahami tentang konsep pembelian perumahan secara Syariah yaitu:

a. Mayoritas masyarakat yang telah memahami bahwa pembelian rumah dengan sistem Syariah lebih menguntungkan ekonomi masyarakat $(55,1 \%)$ dan yang tidak memahami sebesar $44,9 \%$, sosialisasi harus dilakukan secara intens dan menyeluruh ke semua lapisan masyarakat. Edukasi terhadap masyarakat tentang transaksi syariah dewasa ini menunjukan intensitas yang cenderung meningkat, kesadaran masyarakat Muslim Indonesia terhadap transaksi yang dibolehkan dan dilarang semakin mengemuka, kesadaran masyarakat akan haramnya hukum riba semakin baik pula, secara perlahan-lahan masyarakat mulai meninggalkan praktik riba. Efek positifnya adalah semakin banyak masyarakat yang membuka rekening di bank-bank syariah, hal ini merupakan kondisi yang perlu disyukuri bersama dan menjadi peluang dan tugas yang besar bagi pemerintah dan pemegang kepentingan untuk membuka akses yang seluas-luasnya pelayanan bank syariah agar kesadaran dan perwujudannya dapat berjalan secara seimbang (Supeno, 2019).

b. Mayoritas masyarakat yang telah memahami bahwa bertransaksi dengan sistem syariah telah berkonstribusi dalam pengembangan ekonomi umat sebesar 43,2\%, yang tidak memahami sebesar $21 \%$ dan yang ragu-ragu sebesar $38,8 \%$

c. Mayoritas masyarakat telah memahami bahwa pembelian perumahan dengan system Syariah bebas dari riba, denda dan sita yaitu sebesar $54,5 \%$, dan $45,5 \%$ belum memahaminya.

d. Mayoritas masyarakat yang telah memahami kerugian pembelian rumah yang mengandung unsur riba, denda dan sita sebesar 58,3\% dan yang tidak memahami sebesar $41,7 \%$

Dapat disimpulkan bahwa tingkat pemahaman masyarakat terhadap konsep perumahan berbasis Syariah adalah sebagai berikut

a. Mayoritas responden telah memahami bahwa pembelian perumahan secara Syariah akan membantu perekonomian umat $(43.2 \%)$, pertama karena pembelian dilakukan secara kredit yang besarannya sesuai kesepakatan, kedua tidak ada denda keterlambatan, tidak ada finalti, tidak ada sita jika nasabah tidak mampu membayar cicilan.

b. Mayoritas responden yang telah memahami bahwa bertransaksi dengan sistem syariah telah 
berkonstribusi dalam pengembangan ekonomi umat sebesar $43,2 \%$

c. Mayoritas responden juga memahami bahwa pembelian perumahan dengan menggunakan konsep Syariah bebas dari praktik-praktik riba, sita dan denda (54.5\%),

d. Mayoritas responden memahami kerugian yang akan dialami nasabah jika bertransaksi riba (58.3\%).

\section{SIMPULAN}

1. Pada prinsipnya mayoritas masyarakat yang ada dalam Propinsi Jambi telah mengetahui adanya program kepemilikan rumah dengan system Syariah, sedangkan mayoritas masyarakat yang ada dalam Propinsi Jambi belum mengetahui prosedur kepemilikan rumah dengan menggunakan system Syariah;

2. Mayoritas masyarakat telah memahami bahwa pembelian perumahan dengan menggunakan system Syariah lebih menguntungkan ekonomi masyarakat, berkontribusi dalam pengembangan ekonomi umat, memahami bahwa pembelian perumahan dengan system Syariah bebas dari riba, sita dan denda serta memahami kerugian yang dialami jika bertransaksi dengan riba.

\section{DAFTAR PUSTAKA}

Arief Hidayatullah, T. Rifqi Tantawi, Persepsi Masyarakat Kota Bogor Terhadap Skim Pembiayaan KPR Syariah, Jurnal Nisbah, Volume 3 Nomor 1 Tahun 2017

Egi Arvian Firmansyah dan Deru R Indika, Kredit Kepemilikan Rumah Tanpa Bank: Studi di Jawa Barat, Jurnal Managemen Teori dan Terapan, Volume 10 Nomor 3 Tahun 2017

Erwandi Tarmizi, Harta Haram Muammalat Kontemporer, Berkat Mulia Insani, Bogor, 2016

Muhammad Arifin Badri, Panduan Praktis Fikih Perniagaan Islam, Darul Haq, Jakarta, 2015

Muhammad Arifin Badri, Riba dan Perbankan Syariah, Pustaka Al-Furqon, Gresik, 2015

Supeno dan Ansori, Pengembangan Perumahan Berbasis Syariah dan Permasalahannya di Kota Jambi, Jurnal Ilmiah Universitas Batanghari Jambi, Volume 19 (3), Oktober 2019

Viethal Rivai, Islamic Risk Management for Islamic Bank, Gramedia Pustaka Utama, Jakarta, 2013. 